\title{
Portfolio Assessment: Benefits for Students at Different Writing Proficiency Level
}

\author{
Ineng Listiana ${ }^{1}$, Fazri Nur Yusuf ${ }^{2}, \&$ Suci Madiarti Isman ${ }^{3}$

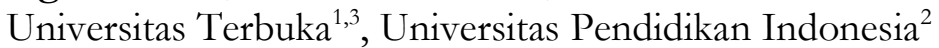 \\ E-mail: listianaineng@gmail.com; fazrinuryusuf@upi.edu; sisman@ecampus.ut.ac.id
}

\begin{abstract}
How to cite (in APA Style): Listiana, I., Yusuf, F.N., \& Isman, S.M. (2020). Portfolio assessment: benefits for students at different writing proficiency level. Jurnal Pendidikan Babasa dan Sastra, Vol. 20(2), 243256. doi:https://doi.org/10.17509/bs_jpbsp.v20i2.33064
\end{abstract}

Article history: (Received: 16 July 2020, Revised: 18 Aug 2020, Accepted: 1 Sept 2020)

Journal homepage: http://ejournal.upi.edu./index.php/BS_JPBSP

\begin{abstract}
This research discusses the effects of portfolio assessment on students' improvement in English writing which are related to their writing proficiency levels, the problems encountered by them in each writing proficiency level, and the solution can be implemented regarding the problems found in the research. The method applied was qualitative method by using test, documentation, and observation instruments to gather the data. All the scores of the tests are arranged in tables based on Wang and Liao's criteria (2008) and are presented in bar chart. The results show that every level of writing proficiency has different percentage of improvement, and the low level students have the least improvement; they produced less sentences. The research also found that every level of writing proficiency had problems which were mainly in content, organization, conventions, and vocabulary, while the low level proficiency had another problem in gaining confidence to produce sentences. Beside that, the students did better in using present tense than past tense, and to improve their writing, it was proven that detailed correction and feedback were effective for the improvement.Thus, it is suggested that teacher should give different portion of attention related to correction and feedback, and the most portion should be given to the low level students of writing proficiency as they have the least improvement. Teacher should also give detailed correction and feedback as well to students to make better improvement.
\end{abstract}

Keywords: correction; feedback; improvement; portfolio assessment; writing proficiency level

\section{Penilaian Portofolio: Manfaat bagi Siswa di Tingkat Kemahiran Menulis yang Berbeda}

\begin{abstract}
Penelitian ini membahas tentang pengaruh asesmen portofolio terhadap peningkatan kemampuan menulis bahasa Inggris siswa yang terkait dengan tingkat kemahiran menulis mereka, masalah yang mereka hadapi di setiap tingkat kemahiran menulis, dan solusi yang dapat diterapkan terkait masalah yang ditemukan dalam penelitian tersebut. Metode yang digunakan adalah metode kualitatif dengan menggunakan instrumen tes, dokumentasi, dan observasi untuk mengumpulkan data. Semua skor tes disusun dalam tabel berdasarkan kriteria Wang dan Liao (2008) dan disajikan dalam diagram batang. Hasil penelitian menunjukkan bahwa setiap tingkat kemampuan menulis memiliki persentase peningkatan yang berbeda, dan siswa tingkat rendah mengalami peningkatan paling sedikit; mereka menghasilkan lebih sedikit kalimat. Hasil penelitian juga menemukan bahwa setiap tingkat kemahiran menulis memiliki masalah terutama pada isi, pengorganisasian, konvensi, dan kosa kata, sedangkan kemahiran tingkat rendah memiliki masalah lain dalam mendapatkan kepercayaan diri untuk menghasilkan kalimat. Selain itu, siswa lebih baik dalam menggunakan present tense dibandingkan past tense, dan untuk meningkatkan kemampuan menulisnya terbukti bahwa koreksi detail dan umpan balik efektif untuk perbaikan tersebut, oleh karena itu disarankan agar guru memberikan porsi perhatian yang berbeda terkait dengan koreksi dan umpan balik, dan porsi terbesar harus diberikan kepada siswa tingkat rendah yang memiliki kemampuan menulis yang paling sedikit peningkatannya. Guru juga harus memberikan koreksi dan umpan balik yang mendetail kepada siswa untuk melakukan perbaikan yang lebih baik.
\end{abstract}

Keywords: koreksi; umpan balik; peningkatan; penilaian portofolio; tingkat kemahiran menulis 


\section{INTRODUCTION}

Portfolio assessment has been practiced by teachers in schools to enhance students's English skills as it is believed to be effective for students. Portfolio assessment as an alternative assessment can support English learning in class by applying it periodically. The advantage of portfolio assessment has been proposed by Demirel and Duman (2015), who conclude that portfolio is beneficial in the skills development of reading, writing and listening, but not speaking.

Regarding the two experts' theory, this research applied portfolio assessment on English writing on Grade VIII students in two classes. It tried to prove their theory about portfolio assessment's benefit on writing skill. Portfolio assessment can be done integrated with the lesson sessions. To make portfolio assessment enjoyable, teacher should play role as trainer, not tester (Weigle, 2005). By doing it as training, students would avoid stress while doing it. They will also get advantage from teacher's feedback later.

One kind of useful feedback is corrective feedback as it can support students to learn more about writing and its elements (AbuSeileek et al. 2014; Dippold, 2009; Recep \& Aysel, 2010 in Saeedi \& Meihami, 2015). This research applied corrective feedback supported with a more detailed correction, which was per word correction. Then the feedback could be done in detail as well to follow the detailed correction.

On the other side, another expert also mentions the benefit of portfolio assessment; Lam (2018), implies that portfolio assessment is useful for students and it is a collection of students' works that show their ability, characteristics, and English skills development. Referring to Lam's theory, the students' works in portfolio assessment in this research should be collected to monitor their progress.

Teacher who does portfolio assessment needs to be prepared with its complex execution. It needs teacher's perseverance to give motivation, to be detail in teaching about the assessment going to be executed by students, to make their works organized, and to evaluate their works in routine (Dudley, 2000 and Kim, 2004 in Caldwell, 2007). A successful teacher is able to make his/her students willingly and happily do portfolio tasks and even to perform them before other people. Beside that, in an ideal portfolio assessment, students are supposed to get improvement every time their work is assessed. This is what was expected in this research.

Concerning about writing proficiency applied in this research, a theory by Benati (2009,p.3) states proficiency has purposes in three main areas; theory and dimensions of second language proficiency, factors contributing to the attainment of second language proficiency, and attaining second language proficiency in the classroom. Theories and dimensions of SLA are related to the knowledge of English theories (reflected from students'proficiency) that is important for students to support their learning in class. As an example, the knowledge of vocabulary of English based on their proficiency level influences them in making verbal sentences. The more proficiency they have, the more they can make verbal sentences (Hall \& Durán in Benati, 2009). In other words, the proficiency owned by someone shows his/her capability in making English verbal sentences. Then the example of factors contributing to the attainment of SLA proficiency is the different usage of language forms between L1 and L2, such as the use of syllables (Hawkins in Benati, 2009). The study of proficiency tries to find the factors contributing to the attainment of second language proficiency as described in the example. For the attainment of SLA, some studies of proficiency try to find the factors in class, one of which is the explicit information in the instruction delivered by teacher in class 
(Patten in Benati, 2009). This research tries to cover the second and third areas of proficiency purposes. First, is to find the causes/factors of students' achievement in writing and second, to describe what proficiency gained in the classroom (in writing).

This research did writing test or assessment of English to students to find writing improvement in the research program. Language testing is done to show a test can produce scores that are accurate in reflecting a participant's ability in certain field (Weir, 2005). The ability could be how to find the main ideas and supporting ideas in a text, how to make a descriptive writing, how to use vocabulary in a writing, and how to speak in peers. For classroom practice, a language assessment is related to learning experiences in a learning environment to find how students achieve language acquisition and communication skill (Fulcher \& Davidson, 2007). This kind of language assessment is suitable and representative for the learners. By knowing their result of learning, it can be figured out how far learners make progress in language practices and in communicating with the language in the learning process. This kind of concept is part of language assessment. It can be concluded from the theories that language assessment means a kind of test to measure learner's language ability, either in spoken or written, that the result of it reflects his/her acquisition of the language and how to communicate with the language. This definition of language assessment was also implemented in this research, especially in writing.

During the research, how portfolio assessment could improve students' writing at different writing proficiency levels is one thing to find, beside the problems encountered by them during the program and the solutions could be implemented by teacher related to the problems. The research involved writing proficiency levels to make the investigation touch every level in the class, so all students could take benefit from this program.

\section{METHODS}

This research was conducted in qualitative study. It implemented portfolio assessment on students' writing skill. The portfolio assessment program itself was applied in two classes of Grade VIII and each class consisted of around thirty two students.

The research was started from case identification; some findings from the previous researchers were studied to find the gap could be investigated. After that, the gap was developed into research problems with study case research. To learn more about the research problems that could be found in the reality, the research did data collecting that it was expected there would be some findings in the investigation. These findings would support the analysis later that was carried on in data analysis step. Finally, after the analysis was done, a report writing was done to describe and to explain the whole research had been conducted.

The instruments used in this research were tests, documentation, and observation. Pre-test and post-test were done by students to produce scores, and later the scores were compared between before and after joining portfolio assessment program. By comparing the two results, it would be known whether there was improvement or not on students' writing performance. In the time between pre-test and post-test, six times portfolio assessments were held to train students' writing skill. The topics of the assessments were Opinion about Something, Making Invitation Card, Simple News, Describing Things, People, Animals, Recount Text, and Interpreting a Song. The scoring used here was adapted and modified from Wang and Liao (2008) which divided it into focus, content, organization, conventions, and vocabulary. The scores range and description were modified to make the scores easier to read and to understand for students.

Then for documentation, the research documented all the research activities in the program. The data gained from this documentation were the 
quantitative data (scores of tests and portfolio assessment of the students ) and the qualitative data in words about students' works, correction, feedback, and observation result in the program.

For the last instrument, observation, qualitative data were gained through observation of the research program when it was being executed. It was done in every meeting held in the program. During the program activity, the research did observation of the students participated in class. This observation was to know how the students did the test or portfolio assessment, their attitude and reaction toward the research program activity being executed in class.

The research did qualitative method to analyze the data. After the data were collected, to analyze them, the research did data reduction, data display, and conclusion drawing. In data reduction, some steps were done; they were summarizing, selecting, focusing, finding pattern, and removing unnecessary data. The research summarized the scores gained in the tests by making scores average, then selected the scores summaries to make the analysis focused. Beside the scores summaries, there were also words data in forms of students' test answers, correction in words, feedback, and observation data. The research focused on the important data that supported the research problems. From the summaries of scores and words data, it could be found the pattern of the research problems; which consisted of the benefit of portfolio assessment, the problems faced by students, and the solutions of the problems. All the data that did not support the analysis of the research problems were removed; for example, the research removed the data of the students who joined pre-test but did not in post-test, because their scores could not be compared and analyzed by then. After the data reduction, the research then displayed the data in commentaries, description, diagrams, categories relationships, chart, and tables. As an example of data display, the number of students who were involved in the research was listed and arranged in tables for the scores data, based on the writing proficiency level. Then the presentation of the average scores data is described in a bar chart.

\section{RESULTS AND DISCUSSION Research Findings}

The first test students joined in this research was pre-test. The pre-test itself consisted of two instructions, which were to make a paragraph of daily activities and a paragraph of impressive experience. A test is held to know students' ability in writing and to produce scores (Weir, 2005; Rao, 2016). Each of the paragraphs in the test was expected to make in $70-100$ words in 30 minutes, so the students would spend an hour to finish the test. The scores resulted are as part of quantitative data in this research.

From the pre-test scores, it was gained the writing proficiency levels of the students (ordinal data) which were divided into three as the following table shows:

Table 1. Writing Proficiency Level Data

\begin{tabular}{ccc}
\hline $\begin{array}{c}\text { Writing Proficiency } \\
\text { Level }\end{array}$ & Scores & Number \\
\hline High Level & $76-88$ & 14 \\
Middle Level & $54-75$ & 29 \\
Low Level & $46-52$ & 14 \\
\hline \multicolumn{2}{r}{ Total } & 57 \\
\hline
\end{tabular}

For the procedure of portfolio, this research implemented a portfolio procedure conceptualized by Srikaew, Tangdhanakanond, and Kanjanawasee 
(2015: p. 768) which consisted of seven steps; planning, preparation for students, evidence collecting, progress monitoring, improvement of performance, reflection and displaying the works. All the steps in the procedure were carefully executed for the sake of portfolio assessment success in this research.

One portfolio assessment implemented for the first time was a writing task with the topic of Opinion about Something, which was about how to express one's opinion about something. Giving opinion is part of argumentative learning and it can be one of students' media to practice English writing as one kind of language assessment (Weir, 2005). In this assessment, the students were asked to see a picture and to give opinion based on the picture in one paragraph with $70-100$ words in 30 minutes.

Before this assessment was done, the research first shew the result of pre-test to the students along with the feedback which was in a per word correction form and there were also some suggestions related to the work. Then they were asked to return their corrected pre-test work to the research to be saved in a folder. The research also asked the students to observe the correction and feedback, in case there was unclear correction or feedback they wanted to ask. For the result of the first assessment, some students were mistaken by making description text rather than giving opinion as it was asked in the task. Nonetheless their scores were better than pre-test's scores.

The second portfolio assessment was Making Invitation Card, in which each student was given a pink or a yellow card to make an invitation card based on the example and the content information in the instruction. The duration was 20 minutes and it was allowed to decorate the card with each student's own imagination based on the topic. The result of this assesment shew the scores increased compared to pre-test's scores.

The third portfolio assessment, Simple News, required students to retell or to paraphrase a simple news about an artist in a paragraph of $70-100$ words in 30 minutes. To make the students more interested in the news, there was a picture of the artist in it. The scores of this assessment were worse than the pre-test scores. The fact shew some students found difficulties to find the approriate words to arrange sentences. Some students also did not apply the correct usage of past tense, for example they still used Verb 1 to express some sentences that should be in past tense (Verb 2).

For the fourth portfolio assessment, the topic was Describing Things, People, Animals with descriptive text form. In the task the students were given three pictures to choose and to be their topic of the descriptive text. The three pictures consisted of a picture of animals, a picture of things, and a picture of people. After the students chose one picture, they should describe it in a short paragraph $(70-100$ words) in 20 minutes. Most of them chose the picture of animals. The scores indicated they did better in this assessment than in pre-test. It was also found that they did present tense better than past tense from this assessment.

The fifth portfolio assessment's topic was Recount Text, in which the students were faced with past tense by making a paragraph of recount text of impressive experience. The research deliberately used this same type of assessment as Simple News (past tense) to make the students more skillful in creating past tense paragraph. The paragraph in the assessment should be in $70-100$ words and the duration was 30 minutes. The scores shew that the students had better scores in doing past tense task than before. The total average score $(69,7)$ is better than the previous past tense task (Simple News) which produced total average score of 59,8 . The students who did the test just by continuimg the sentences from the example were less than those in the previous past tense task in the pre-test. There were more students who creatively 
made their own sentences from the beginning of the work in this assessment.

In the last/sixth assessment, Interpreting a Song, the task was the most difficult among all the tests or assessments programmed in the research. It was about how to interpret a song. Songs are like poems, they often contain words with connotation, ambiguity, and complexity of meaning. The research included this topic to give students a new language learning experience as part of portfolio (Ibid, 1991 in Kühn \& Cavana, 2012). To make the task simpler and easier, the song taken was one that became favourite song among the students which was produced in early 2019. However it seemed that they still found difficulties in this song. The total average score resulted from this assessment was the lowest among the other scores of tests/assessments. However, some students could perform the task well, which means they understood and could interpret the song.

At the end of the program, a post test was held. Post-test is done to reflect accurately students' ability (Weir, 2005). It is also for checking students' progress in learning as part of the learning itself (Fulcher \& Davidson, 2007). The scores in the post-test informed that they were better than pre-test scores.

Post-test in this program had the same type of test as pre-test's. It consisted of two instructions which were about hobbies and unpleasant experience. The first instruction was to tell about hobbies; the kind of hobby/hobbies, where to do it, how to do it, with whom to do it, how much the cost was, what equipment to do it, etc. The second instruction was to tell an unpleasant experience which was in past tense. Only a few students who just continued the story from the example sentences. The others had more creative thinking in writing their own stories.

After the execution of all the program activities, the findings in the quantitative data can be summarized as follows:

Table 2. Comparison between Pre-Test and Post-Test Scores

\begin{tabular}{|c|c|c|}
\hline Test & Pre-test & Post-test \\
\hline Content & 65,6 & 75,6 \\
\hline Conventions & 62,6 & 69,3 \\
\hline Focus & 68,5 & 78,0 \\
\hline Organization & 63,9 & 73,2 \\
\hline Vocabulary & 68,0 & 73,5 \\
\hline
\end{tabular}

The table performs that there is an improvement achieved by the students, which means the study succeeded in implementing portfolio as a way to improve students' writing performance. The bar chart of the above table is described below: 


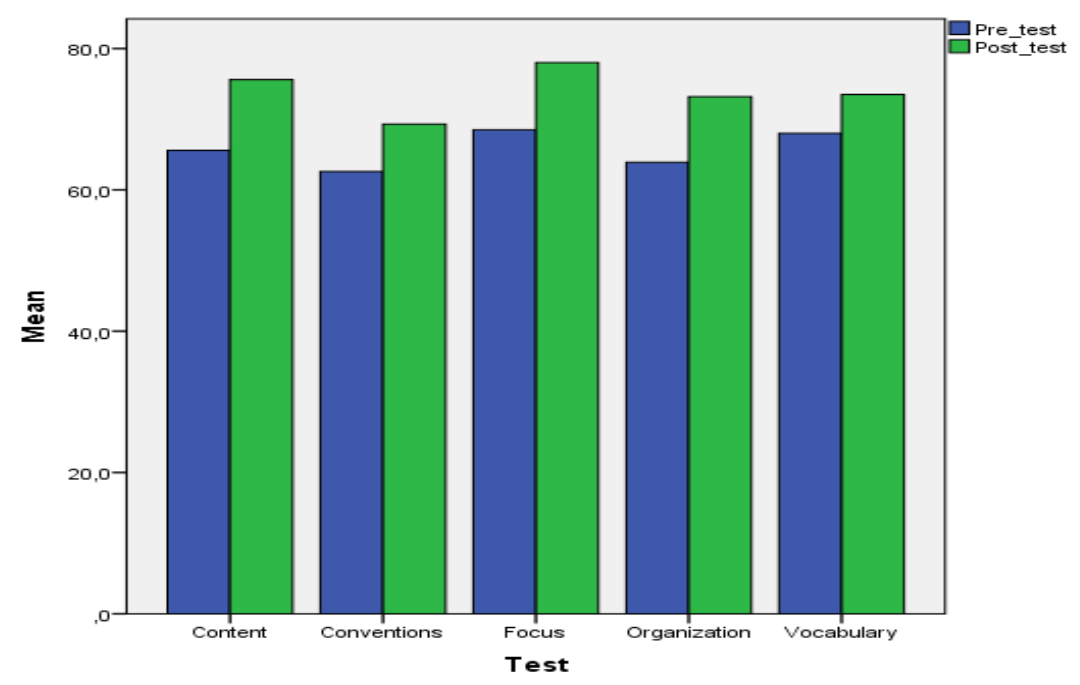

Figure 1. Bar Chart of Pre-test and Post-test in the Research Program

Another fact indicated that not all participants had improvement in the program, but many of them had, which were 41 students. It means the number of students who did not get improvement was 16. To give the detail description, below is the data of the improvement per level of writing proficiency:

Table 3. Number of Students with Improvement and not

\begin{tabular}{lcc}
\hline $\begin{array}{l}\text { Level of } \\
\text { Writing } \\
\text { Proficiency }\end{array}$ & $\begin{array}{l}\text { Number of students who } \\
\text { had improvement }\end{array}$ & $\begin{array}{l}\text { Number of students who did not } \\
\text { have improvement }\end{array}$ \\
\hline High & 10 & 4 \\
Middle & 22 & 7 \\
Low & 9 & 5 \\
Total & 41 & 16 \\
\hline
\end{tabular}

From the table above it can be calculated that the number of high level students who had improvement is 71,43 $\%$, the middle level students have $75,86 \%$, and the low level students have 64,29\%. The data inform that the middle level students have the highest improvement in percentage, while the low level students have the lowest improvement.

On the other hand, the students who were stable in scores were 2 (the score of pre-test was the same as the post-test's), which means they did not have improvement nor decrease in the research program. For the students who had decrease score, the number is 14 .

The qualitative data in this research are the ordinal data of writing proficiency levels (as described before), words data in students' works, correction in words, commentaries in feedback, and observation data. In this program, the research held feedback sessions twice. Feedback is important in this program as part of improvement step done by teacher. Feedback should follow portfolio assessment (Burner, 2014 in Lam, 2018) and supports teaching and learning improvement in writing in classroom (Lam, 2018).

As a description in the portfolio assessment program, in each work, the raters did correction per word and gave suggestions for the right words or sentences, so the students could know exactly their mistakes were and could try to remember them, hence they would never repeat the same mistakes in the next 
writing tasks. The following texts documentation will show the examples of correction and feedback activities that were taken from some of the participants's writing works.
This is one example from pre-test work that is about daily activities with the correction and feedback:

The other example here is a work of a student which is about Simple News:

The news is about an Indonesian artist, Jessica Mila. She is 21 years old. She willing to up ${ }^{\text {increased }}$ her weight untill-10 kg. She de $\theta^{\text {did }}$ it because she played a role as Rara in "Imperfect: Karir, Cinta, dan Timbangan" film. The trailer movie ${ }^{\text {trailer }}$ has ${ }^{\text {was }}$ published ${ }^{\text {uploaded }}$ when ${ }^{\text {on }}$ Thursday $(19-9-2019)$ with duration of \pm 40 seconds.

In that trailer, the point view is a moment ${ }^{\text {setting was }}$ in an office. There is ${ }^{\text {was }}$ a wome ${ }^{\text {a }}$ n with purple work ${ }^{\text {ing }}$ clothes, walk ${ }^{\text {ed }}$ elegant ${ }^{\text {ly }}$. Then ce- ${ }^{\mathrm{a}} \mathrm{me}$ a wome ${ }^{\mathrm{a}} \mathrm{n}$ with long curly hair, follow ${ }^{\text {ing }}$ her with two lunch box ${ }^{\mathrm{es}}$. The woman with purple clothes curly hair wome ${ }^{a}{ }^{\text {followed }}$. And may be will made you confused ${ }^{\text {it will make }}$ you surprised, .....

Suggestions:

- Learn more how to use past tense, especially how to use the verb (Verb 2), "was", "were".

- The single form of "women" is "woman".

\section{Analysis}

After the findings attained in this study, the analysis of the research are described in the following explanation:

\section{1) The benefits taken by each writing proficiency level}

\section{a) The low level of writing proficiency}

The only advantage this level students could get was to have experience of joining writing training in a portfolio assessment form so they would know more about writing, based on the various topics offered in the program. A new language learning experience is part of portfolio assessment (Ibid, 1991 in Kühn \& Cavana, 2012).

On the other hand, this level had the least improvement among the levels, even some of the low level students almost did not have any improvement in the program. 
Moreover some of their scores decreased in the post-test. There are some factors can influence student's perfomance in portfolio assessment (Hawkins in Benati, 2009 \& Patten in Benati, 2009). They might feel that they did not have to be serious in this program since the scores did not influence their final scores report in this semester, as it had been told before the program was started. From the observation it was found that they were reluctant to produce more sentences although the research had encouraged them to do so, since the remaining time was still much.

\section{b) The middle level of writing proficiency}

This level students have the highest improvement based on the number who had improvement. It means portfolio assessment gave some benefits to them (Demirel \& Duman, 2015 \& Nicolaidou, 2012). It can be implied that the advantages they could take were to have the experience of English writing training with various topics (Ibid, 1991 in Kühn \& Cavana, 2012), to be monitored and paid attention by the two raters with results of correction and feedback, to be encouraged to produce better in writing, to know their real writing performance after receiving feedback (Lam, 2018). By knowing that their writing could be improved, they might like writing more than before.

\section{c) The high level of writing proficiency}

Some of the scores of the high level students decreased in the post-test. There are some causes of decrease in language learning (Hawkins in Benati, 2009 \& Patten in Benati, 2009), The research analyzed that this fact is caused by their lower motivation in the end of the program (for those whose scores decreased). The cause might be the same as the lower level's cause that is the feeling that this program was not necessarily done in a serious way since the scores did not influence the semester final report. It might also be caused by their overconfidence by the feeling of being part of the best in class that they tended to underestimate the program. The research observed that although they were told the remaining time was still much to do the task, they were not so encouraged to produce better in writing although they had received feedback. Due to this fact, the benefit gained by this level of writing proficiency was the same as the low level.

\section{2) Problems encountered at different writing proficiency levels during portfolio assessment \\ implementation}

The research held six times portfolio assessments to give students writing training. It is in line with the role of portfolio as a training, not a test (Weigle, 2005; Lam, 2018; Burner, 2014 in Lam, 2018). During the program, there were some problems faced by students. For global investigation, the research displays the analysis of the problems encountered by the participants based on the criteria of Wang and Liao (2008). The problems were related to students' performance improvement in the program. Hence to know the improvement, below is the overall statistics based on Wang and Liao's criteria (2008) as a reference: 


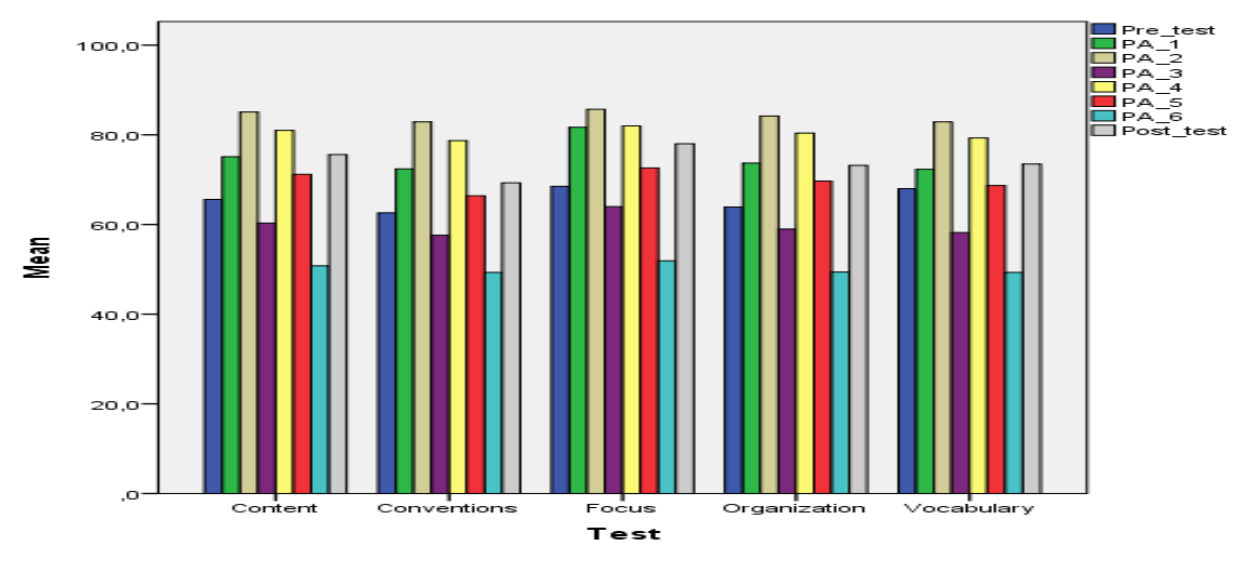

PA: Portfolio Assessment

Figure 2. Overall statistics of the scoring

\section{a. Focus}

Focus has the highest score in each test/assessment in average for all levels. It seemed that it was not so hard for the students to keep on the topic they were working on in their writing.

\section{b. Elaboration/Content}

Content is the second highest score in the research result for all levels. It shows that the students in average could make the detail of the topic with their own ideas or imagination. Only a few students did not make the detail of the topic well, and they were the students with low scores of test in the other criteria of scoring. Many of the students who made low scores in conventions and vocabulary, also made low scores in content. It means the students who found hard to make sentences or to find appropriate vocabulary, also felt hard to make the details of the topic they were working on. This finding could be seen in the following table (as an example):

Table 4. Selected Students' Scores

\begin{tabular}{cccccccc}
\hline & & \multicolumn{5}{c}{ Scoring Citeria } \\
\cline { 3 - 6 } No. & Name & Focus & $\begin{array}{l}\text { Elaboration/ } \\
\text { Content }\end{array}$ & $\begin{array}{l}\text { Organi- } \\
\text { zation }\end{array}$ & $\begin{array}{l}\text { Conven- } \\
\text { tions }\end{array}$ & $\begin{array}{l}\text { Vocabu- } \\
\text { lary }\end{array}$ & Total \\
\hline 1 & Student 54 & 50 & 45 & 45 & 50 & 50 & 48 \\
2 & Student 42 & 60 & 50 & 55 & 50 & 55 & 54 \\
3 & Student 3 & 60 & 60 & 60 & 60 & 60 & 60 \\
4 & Student 1 & 90 & 90 & 80 & 70 & 80 & 82 \\
5 & Student 2 & 90 & 90 & 85 & 80 & 85 & 86 \\
\hline
\end{tabular}

\section{c. Organization}

From Table 4 above, it is seen that organization is also influenced by conventions and vocabulary. That is the research analysis from the portfolio program. In this research, organization is the third position of scores in average. It indicates that for all levels, organization is neither so difficult nor so easy. Only students with low confidence of making sentences produced failed organization in their writing. It can be seen from their less production of sentences or words.

\section{d. Conventions}

The tests and the assignments in this research instructed the participants to write in present tense or past tense. From the average scores it can be seen that most of them had more obstacles in making past tense sentences than present tense ones. It can be observed in Figure 2 that shows PA 3 and PA 5 which are about past tense that 
have lower bars compared to the other criteria (except for PA 6).

\section{e. Vocabulary}

Many students could not find the appropriate words for their sentences or used the wrong word classification. Some of them even asked the research some English words they could not find in their dictionary and the research limited only three questions of English words for each student.

Related to the usage of verbs, some students could not differentiate single and plural words, for example: they used $\mathrm{V} 1+\mathrm{s}$ for plural words, they used it as the pronoun of a plural word. Some of them could not differentiate how to use pronoun as an object and pronoun as a possession, for example: them and theirs, him and his.

3) Solutions implemented by teacher to solve the problems encountered by students during portfolio assessment program

a. Giving frequent feedback to students

This research gave importance to feedback in every test/assessment. Feedback plays an important role in portfolio (Lam, 2018; Burner, 2014 in Lam, 2018; Srikaew, Tangdhanakanond, \& Kanjanawasee, 2015). Some students were encouraged by feedback, beside the detailed correction per word given by the raters. By this feedback, they might feel being monitored by the raters so that they felt they should appreciate it by doing better wirh their best performance in the assessments. In the correction, if it was found that some students made unclear sentences, the research gave examples of the other alternative sentences to give clearer meaning to their sentences.

There were four kinds of constructive feedback should be given to students, so portfolio assessment would be more effective to students, they are: negative feedback, that is corrective comments about the work has been done by students; positive feedback, that is affirming comments about the work has been done by students; negative feedforward, that is corrective comments about the mistakes should be avoided in the future; and positive feedforward, that is affirming comments about the things that will improve students' work in the future.

\section{b. Giving detailed correction and feedback}

Detail correction (per word) and feedback would make clearer the steps the students had to do to improve their writing. By understanding and memorizing their mistakes and the correction, they would not make the same mistakes or at least lessen their mistakes. It can also build students' writing self-efficacy as Bandura proposes (Nicolaidou, 2012). This fact was proven by the research in the program as it has been explained in the previous sections.

\section{c. Informing the students what they had developed their writing skills}

By informing the students' writing skill development, the students could measure their capability by themselves and make strategies to improve it. This skill development information can actually be done by teacher regularly, for example once a month or twiuce a month. By knowing their own skill development, they could always monitor their own skill. It is also one of portfolio assessment's benefits as a collection of a person's work to improve his/her writing performance (Lam, 2018; Ibid, 1991 in Kühn \& Cavana, 2012; Nicolaidou, 2012). The informing activity was included in the program that was implemented in feedback activities.

\section{Conclusions and Suggestions}

After conducting the research, there are three conclusions can be derived from the findings and the analysis: the first conclusion is that every level of writing proficiency received the benefits of portfolio, at least the benefit of having experience of joining writing training in a portfolio assessment form so they would know more about writing, based on the various topics offered in the program. For the second conclusion, the problems 
encountered by students were in the criteria of content, organization, conventions, and vocabulary-based on Wang and Liao's criteria (2008). Scores in content and organization are influenced by the ability of conventions and vocabulary. For the third conclusion, the solutions applied by the research to help students face their problems were by giving frequent feedback to students, by giving detailed correction and feedback to students, and by informing the students what they had developed their writing skills.

Following the conclusions, suggestions are offered by the research, which are: (1) teacher should apply portfolio-especially in writing-and realize the benefits of it at every level of proficiency in class by conducting portfolio assessment program with the best performance; (2) teacher should be aware of the problems students may encounter in the portfolio assessment program being executed, so that he/she could do every necessary action to help them solve the problems; (3) the steps of activities in this research should be applied in writing portfolio assessment by teacher, especially for Grade VIII students, to support English learning in class; (4) the findings in this study should become reference for the next research about portfolio assessment, especially in English writing of Junior High School.

\section{ACKNOWLEDGMENTS}

Special gratitude is delivered to Allah SWT, the people and the institutions supported this research. They are all the staffs of Universitas Terbuka who helped the writers in the research process, Universitas Terbuka of Bandung and Jakarta, SMPN 03 Batang, and all the writers whose works are quoted in the article.

\section{REFERENCES}

AbuSeileek, A., \& Abualsha'r, A. (2014). Using peer computer-mediated corrective feedback to support EFL learners' writing. Language Learning \& Technology, 18(1), 76 - 95. Retrieved from wnw.tewtjoumal.org. Accessed on July 21, 2020.

Benati, A. G. (2009). Issues in Second Language Proficiency. New York: Continuum International Publishing Group.

Burner, T. (2014). The potential formative benefits of portfolio assessment in second and foreign language writing contexts: A review of the literature. Studies in Educational Evaluation, vol. 43, 139-149.

Caldwell, D. (2007). Teacher perceptions on student portfolio assessment and implementation. New Jersey: A Thesis of Master of Arts Degree of the Graduate School at Rowan University.

Demirel, M., \& Duman, H. (2015). The use of portfolio in English language teaching and its effects on achievement and attitude. Procedia: Social and Behavioral Science, vol. 191, 2634 - 2640. Retrieved from wnm.sciencedirect.com. Accessed on March 9, 2019.

Dippold, D. (2009). Peer feedback through blogs: Student and teacher perceptions in an advanced German class. ReCALL, 21(1), 18-36.

Dudley, M. (2001). Speaking my mind: Portfolio assessment: When bad things happen to good ideas. The English Journal, 90(6), 19-20.

Fulcher, G., \& Davidson, F. (2007). Language Testing and Assessment: An advanced resource book. Oxon: Routledge.

Hall, C. J., \& Durán, A. R.. (2009). Crosslinguistic influence in L2 verb frames: The effects of word familiarity and language proficiency in Issues in second language proficiency, A. 
G. Benati. p. 24. New York: Continuum International Publishing Group.

Hawkins, R. (2009). Statistical learning and innate knowledge in the development of second language proficiency: Evidence from the acquisition of gender concord in Issues in second language proficiency, A. G. Benati. p. 63. New York: Continuum International Publishing Group.

Kim, Y. (2004). Teacher's perspectives, self-reported practices, and concerns related to the Illinois alternate assessment system. ProQuest Information and Learning Company.

Kühn, B., \& Cavana, M. L. P. (2012). Perspectives from the European Language Portfolio. Oxon: Routledge.

Lam, R. (2018). Portfolio Assessment for the Teaching and Learning of Writing. Singapore: Springer Nature.

Meihami, H., \& Saeedi, Z. (2015). Eportfolio as a corrective platform towards EFL students' overall/componential writing performance. Teaching English with Technology, 15(4), 76 - 97. Retrieved from wnw.tewtjournal.org. Accessed on July 21, 2020.

Nicolaidou, I. (2012). Can process portfolios affect students' writing self-efficacy. International Journal of Educational Research, vol. 56, 10 - 22. Retrieved from mmn.elsevier.com. Accessed on April 12, 2019.

Patten, B. V. (2009). Formal intervention and the development of proficiency:
The role of explicit formation in Issues in second language proficiency, A. G. Benati. p. 169. New York: Continuum International Publishing Group.

Rao, V. C. S. (2016). A brief study of English language proficiency: employability. English for Specific Purposes World, vol. 17, issue 49.

Recep S. A., \& Aysel, S. (2010). How can the use of blog software facilitate the writing process of English language learners? Computer Assisted Language Learning, 23(3), 183-197.

Srikaew, D., Tangdhanakanond, K., \& Kanjanawasee, S. (2015). Development of an English speaking skill assessment model for grade 6 students by using portfolio. Procedia: Social and Behavioral Sciences, vol. 191, 764 - 768. Retrieved from wnw.sciencedirect.com. Accessed on March 9, 2019.

Wang, Y. H., \& Liao, H. C. (2008). The application of learning portfolio assessment for students in the technological and vocational education system. Asian EFL Journal, 10(2), 132-154.

Weigle, S. C. (2005). Second language writing expertise in Expertise in language learning and teaching, $\mathrm{K}$. Johnson. pp. 128-149. Hampshire, England: Palgrave Macmillan.

Weir, C. J. (2005). Language Testing and Validation: An Evidence-based Approach. New York: Palgrave Macmillan. 
Listiana, Yusuf \& Isman, Portfolio assessment: benefits for students at different writing ... 